\title{
Experiment and Simulation Study of Single Cylinder Diesel Engine Performance, Using Soybean Oil Biodiesel
}

\author{
Muhammad Rizqi Ariefianto, Aguk Zuhdi Muhammad Fathallah, Wolfgang Busse \\ Jurusan Teknik Sistem Perkapalan, Fakultas Teknologi Kelautan, Institut Teknologi Sepuluh Nopember \\ J1. Arief Rahman Hakim, Surabaya 60111 Indonesia \\ e-mail: fathalaz@its.ac.id
}

\begin{abstract}
The most common fuel uses in the world is made from fossil. Fossil fuel is categorized as a nonrenewable energy source. For that reason, there should be an alternative fuel to replace fossil fuel by using biodiesel and one of the stock comes from soybean bean. Before using the biodiesel made from soybean bean oil, there should be a research to find out the properties and the effect of biodiesel from soybean bean oil regarding the performance of the engine. The research can be conducted in experiment and simulation. The properties result of soybean oil biodiesel should be tested to confirm whether this biodiesel have meet the standard requirement of biodieselor not. This biodiesel sproperties are Flash Point value is $182^{\circ} \mathrm{C}$, Pour Point value is $-7^{\circ} \mathrm{C}$, Density at $15^{\circ} \mathrm{C}$ is $890 \mathrm{Kg} / \mathrm{m3}$, Kinematic Viscosity at $40{ }^{\circ} \mathrm{C}$ is 5.58 (cSt), and Lower Heating Value is $42.27686 \mathrm{MJ} / \mathrm{kg}$. The result from this research is the highest power from simulation is $9 \%$ higher than the experiment. The highest torque from the experiment is $37 \%$ lower than the simulation's torque. Lowest SFOC from experiment is $\mathbf{2 8 \%}$ lower than the simulation's SFOC. Highest BMEP from simulation is $20 \%$ higher than the highest BMEP from experiment. The highest thermal efficiency from experiment is $6 \%$ higher than the highest thermal efficiency from simulation. The engine performance result using soybean oil biodiesel is not better than the Pertamina Dex. For that reason, the use of this biodiesel is not suggested to substitute Pertamina Dex.
\end{abstract}

Keywords - Biodiesel, Power, Torque, SFOC, BMEP, Thermal Efficiency.

\section{INTRODUCTION}

$\mathrm{F}$ uel considered as the most essential item to provide the energy in this era. Nowadays, the most common fuel uses in the world is made from fossil. It is because fossil fuel has high contents of carbon which is needed for combustion process. Fossil fuel is categorized as a non-renewable energy source. It means that this energy source stock is limited and have finite amounts. This fossil took million years to transform to oil and it will be run out in the matter of time. In this time, the using of fossil fuels is become a discussion among the scientist, engineer and ordinary people. It is because the amounts of fossil fuels in the critical point that's why there are some increasing price of fuel oil in some areas. For that reason, there should be an innovation of new source of energy which is renewable and have infinite amounts. One of the alternative fuel comes from biodiesel.

Biodiesel is one of alternative energy which is renewable. It means biodiesel comes from the resources which is can be regenerated in a short of time. Biodiesel is defined as a fuel comprised of mono-alkyl esters of long chain fatty acids derived from vegetable oils or animal fats. ${ }^{[1]}$ This kind of fuel can be used as fuel in diesel engine. Biodiesel comes from many resources such as vegetable oil, animal oil, etc. Vegetable oil is an oil which is made from plants such as palm oil, soybean bean oil, rapeseed oil, etc. Biodiesel from vegetable oil is considered as ecofriendly fuel. This biodiesel does contains any low Sulphur content and it produce more harmless emission. ${ }^{[2]}$

One of the stock for biodiesel comes from soybean. Ethanol can be produced by soybeans. It is can be used to biodiesel production. Soybean hulls contain significant amount of carbohydrate for ethanol production. [3] soybean biodiesel have separate processes in oil extraction and biodiesel conversion. The oil extraction can be done by using mechanical presses, solvent extraction, supercritical fluid extraction and microwaveand ultrasound-assisted solvent extractions. Transesterification method can be used to convert extracted oil to biodiesel. ${ }^{[4]}$

Before using the biodiesel made from soybean bean oil, there should be a research to find out the effect of biodiesel from soybean bean oil regarding the performance of the engine. This research shall be taken to determine the potency of soybean bean oil biodiesel for the future and is it be able to substitute the fossil fuel oil into this biodiesel in the future. Besides that, the research should be done very carefully for the precision result and for the continuous research in the future. The research of engine performance analysis using soybean oil biodiesel can be done experimentally with the results of the data in the field and simulation by modeling experiments using the simulation in order to cut the experiment's cost. ${ }^{[5]}$

\section{RESEARCH METHODOLOGY}

\section{A. Design Experiment}

Design experiment is the planning, conducting, and analyzing of experiment. Design experiment will provide the best result of experiment. With good plan of the experiment will support to achieve the objective and the experiment will be well executed. This process also will provide good information to be analyzed.

\section{B. Biodiesel Production and Properties Test}

In this step biodiesel will be produced using kitchen equipment. Production of biodiesel using transesterification process based on the reference. In this 
process also conduct equipment and material preparation for producing biodiesel. This test is conducted to know the succes level of the production process. This test also will show the information whether this type of biodiesel meet the requirement of national biodiesel standard or not. The biodiesel properties that will be tested are: viscosity, density, flash point, pour point, and lower heating value.

\section{Engine Setup}

Engine setup is a process of arranging the system configuration for the experiment. The engine setup will be shown in figure below.

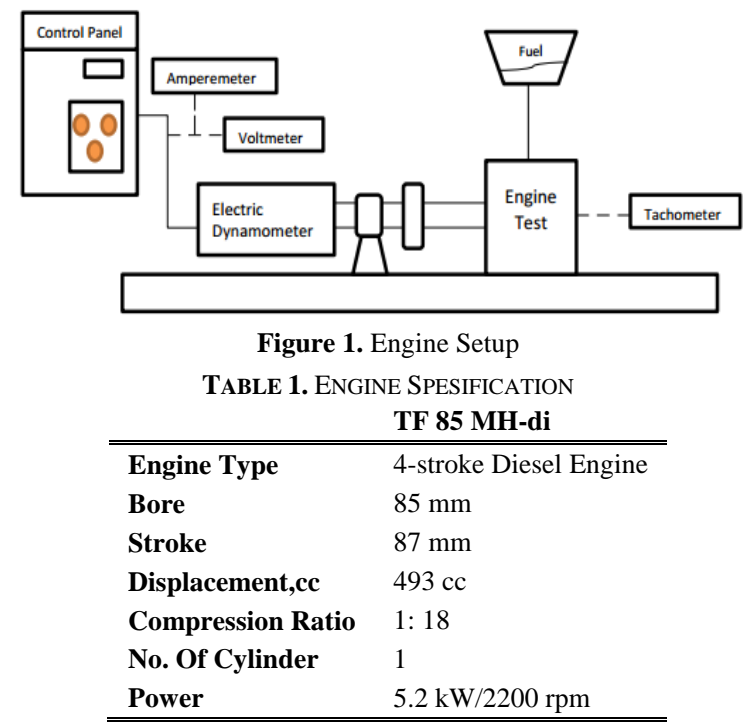

\section{Engine Modelling}

Variable input is the procedure in this research is taken by opening the diesel engine and measure the components for the model. At this point the modelling will be designed. Variable input will be stored to simulate the model of the engine. The engine spesification is one of the requirement to input the variable.

\section{RESULT AND DISCUSSION}

\section{A. Making Soybean Oil Biodiesel}

In this experiment, biodiesel is produced from soybean oil. The production of this biodiesel is using transesterification method using metoxide which ithe mixture is made by mixing the methanol and $\mathrm{KOH}$. This process also conducted using kitchen tools. The material that will be used in this process are :

- Soybean Oil

- Methanol

- $\mathrm{KOH}$

- Aquades

Some equipments that will be used in this process are :

- Bottle

- Measuring cup

- Stove

- Blender

- Scale

- Thermometer

\section{1) Mixing the Metoxide}

Measure $200 \mathrm{ml}$ of methanol and $5 \mathrm{gr}$ of $\mathrm{KOH}$. Pour methanol into glass bottle (don't use plastic bottle (PET) because this mixture can react to plastic). Put 5 gr of $\mathrm{KOH}$ inside the glass bottle within methanol inside the bottle. Close the cap of the bottle tightly. Methanol and $\mathrm{KOH}$ can absorb the water from the atmosphere. Make sure do this process fast and the cap already tighten.

Swirl round the bottle to mix this mixture. In this process will increase the temperature of this mixture so the mixture will get hot. Swirl it until all $\mathrm{KOH}$ content dissolve in methanol. This mixture is called metoxide. As the metoxide looks clear without any undissolved particles, this mixture can be used for the process.

\section{2) Pre Heating}

Measure 1 litre of soybean oil and pour it into pan. Pre heat the soybean oil using the stove until it reach $55^{\circ} \mathrm{C}$. Make sure the oil temperature below $60^{\circ} \mathrm{C}$ because this oil will be mixed with the metoxide and metoxide will evaporate if the temperature over $60^{\circ} \mathrm{C}$.

\section{3) Biodiesel Processing}

Using blender, pour the heated soybean oil and and metoxide inside the blender. Make sure the blender seals in good condition and the blender in dry and clear condition. Turn on the blender in low speed for 20-30 minutes.

4) Settling

Pour the blended mixture into bottle and close the cap tightly. Allow this mixture to settle for minimum 12 hours. This mixture will be divided into two layers. Darker colour is called glycerine. Glycerine will collect in distinct layer at the bottom of the bottle. Clearer and yellow colour is called biodiesel. This biodiesel layer will stay above the glycerine.

5) Washing

Add $500 \mathrm{ml}$ of aquades into biodiesel bottle. Stir it slowly until the aquades will separate in the bottom of the bottle. Do this process for 2-3 times. On first wash, add $500 \mathrm{ml}$ of aquades into biodiesel bottle. Stir it slowly until the aquades will separate in the bottom of the bottle. Do this process for 2-3 times. In this process the volume of biodiesel is $1070 \mathrm{ml}$ and $500 \mathrm{ml}$ of aquades. The result of this washing process is $500 \mathrm{ml}$ of biodiesel. After the washing process has finished, separate the aquades from the biodiesel.

6) Drying

For drying the biodiesel, pour washed biodiesel into pan. Heat the biodiesel until $100^{\circ} \mathrm{C}$. This process will evaporate the water content in biodiesel. After all the water content evaporate, the result is biodiesel within volume of $450 \mathrm{ml}$.

\section{7) Properties Test}

This test goal is to make sure this soybean oil biodiesel meet the requirement of National Biodiesel Standard. This test also conduct to check the quality of this biodiesel. The test is conducted in Energy Laboratory ITS the test result will be shown on the table below. From the table 2, soybean oil biodiesel meet the requirement of SNI standard for biodiesel. The table show soybean oil biodiesel have $0 \%$ of error regarding all parameter that has been tested. 


\section{B. Engine Performance Comparison Result between Experiment and Simulation.}

To determine the potential of soybean oil biodiesel mixture, there should be a study on engine performance using soybean oil biodiesel mixture. Engine Performance can be conducted experiments and simulations. Several parameters were taken in the study include the Power, Torque, SFOC, BMEP, and Thermal Efficiency. Fuel used in this research are Pertamina Dex, B10 (10\% biodiesel and $20 \%$ Pertamina Dex), and B20 (20\% biodiesel amd 80\% Pertamina Dex)

\begin{tabular}{clcc}
\multicolumn{4}{c}{ TABle 2. Soybean Oil Biodiesel Properties } \\
No. & \multicolumn{1}{c}{ Parameter and Unit } & Value & Method \\
\hline \hline 1. & Flash Point, ${ }^{\circ} \mathrm{C}$ & 182 & ASTM D-92-05 \\
2. & Pour Point, ${ }^{\circ} \mathrm{C}$ & -7 & ASTM D-92-02 \\
3. & Density at $15^{\circ} \mathrm{C}, \mathrm{Kg} / \mathrm{m} 3$ & 890 & ASTM D-1480 \\
4. & Kynematic Viscosity at $40^{\circ} \mathrm{C},(\mathrm{cSt})$ & 5,58 & ASTM D-445-97 \\
5. & Lower Heating Value, $\mathrm{MJ} / \mathrm{kg}$ & 42,272686 & - \\
\hline \hline
\end{tabular}

Figure 2 is graph of the comparison result between maximum power and rpm for each fuel and each method. The highest power is produced at $2200 \mathrm{rpm}$ for fuel and each method. Pertamina Dex Simulation produce the higher power of $4.21968 \mathrm{~kW}$ than Pertamina Dex Experiment's power that produce value of $3.93786 \mathrm{~kW}$. B10 Simulation produce the higher power of $4.21332 \mathrm{~kW}$ than B10 Experiment's power that produce value of $3.73065 \mathrm{~kW}$. B20 Simulation produce higher power of $4.20257 \mathrm{~kW}$ than B20 Experiment's power that produce value of $3.7288 \mathrm{~kW}$. The difference between highest power for the fuel is about $5 \%$ and between both method is about $13 \%$.

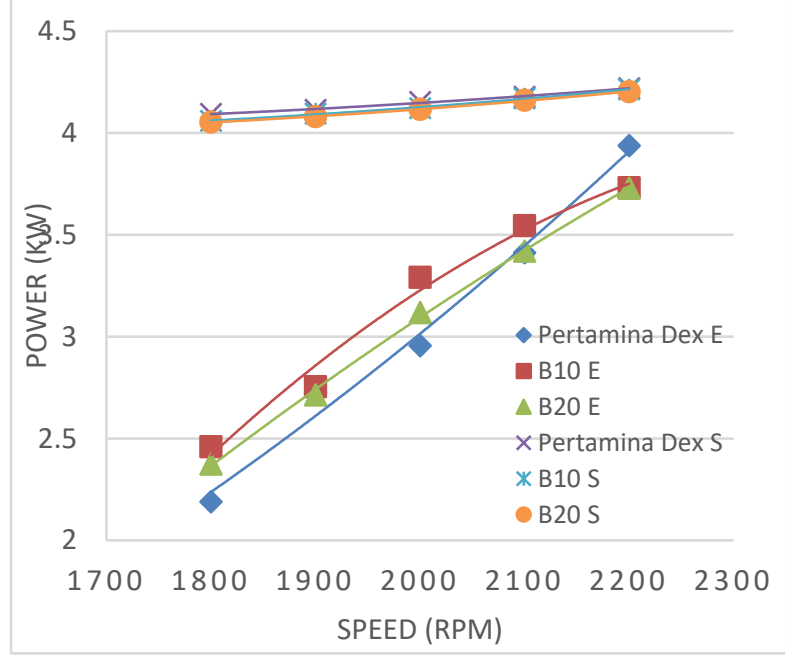

Figure 2. Graph of Power Vs RPM.

Figure 3 is a graph of the comparison result between maximum torque and rpm for each fuel and each method. The highest torque is produced in $1800 \mathrm{rpm}$ for simulation and at $2200 \mathrm{rpm}$ for the experiment. Pertamina Dex simulation produce the highest torque of $21.72951 \mathrm{Nm}$ and Pertamina Dex experiment's Produce $17.1013 \mathrm{Nm}$ for the highest torque. B10 simulation produce the highest torque of $21.54671 \mathrm{Nm}$ and B10 Experiment Produce 16.20143Nm for the highest torque. B20 simulation produce the highest torque of 21.51332 $\mathrm{Nm}$ and B20 Experiment Produce 16.1934 for the highest torque. The difference between highest torque for the fuel is about $5 \%$ and between both method is about $37 \%$.

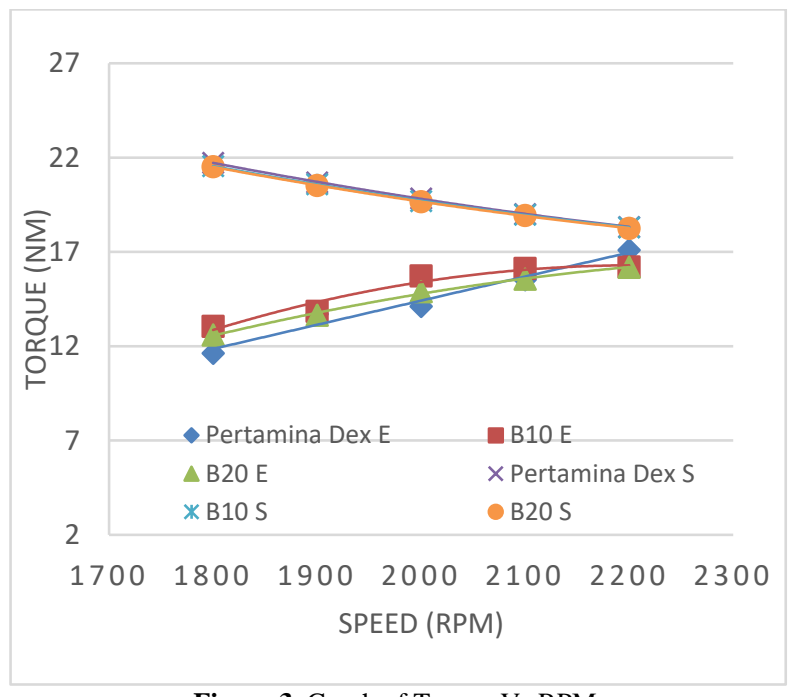

Figure 3. Graph of Torque Vs RPM.

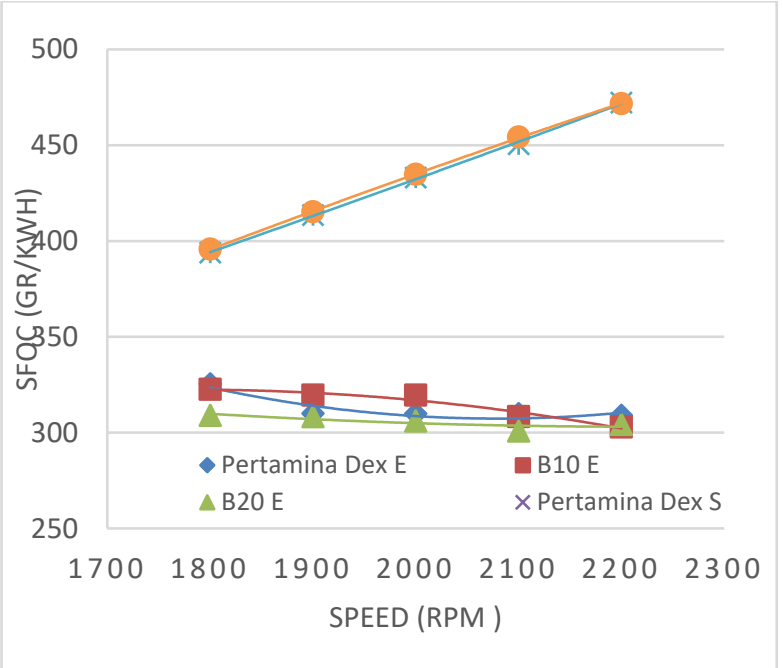

Figure 4. Graph of SFOC Vs RPM

Figure 4 is a graph of the experiment and simulation comparison result between SFOC and rpm in maximum power for each fuel and each method. At the $1800 \mathrm{rpm}$ for Pertamina Dex simulation show the lowest value of SFOC but Pertamina Dex experiment's show the lowest value at $2200 \mathrm{rpm}$. Pertamina Dex simulation SFOC value at $1800 \mathrm{rpm}$ is $395.642 \mathrm{gr} / \mathrm{kWh}$ and Pertamina Dex simulation SFOC value at $2200 \mathrm{rpm}$ is 468.664 $\mathrm{gr} / \mathrm{kWh}$. For Pertamina Dex experiment, SFOC value at $1800 \mathrm{rpm}$ is $325.362 \mathrm{gr} / \mathrm{kWh}$ and at $2200 \mathrm{rpm}$ is 309.02 $\mathrm{gr} / \mathrm{kWh}$. At the $1800 \mathrm{rpm}$ for B10 simulation show the lowest value of SFOC but B10 experiment's show the lowest value at $2200 \mathrm{rpm}$. B10 simulation SFOC value at $1800 \mathrm{rpm}$ is $393.876 \mathrm{gr} / \mathrm{kWh}$ and B10 simulation SFOC value at $2200 \mathrm{rpm}$ is $472.164 \mathrm{gr} / \mathrm{kWh}$. For B10 experiment, SFOC value at $1800 \mathrm{rpm}$ is $322.578 \mathrm{gr} / \mathrm{kWh}$ and at $2200 \mathrm{rpm}$ is $302.918 \mathrm{gr} / \mathrm{kWh}$. At the $1800 \mathrm{rpm}$ for B10 simulation show the lowest value of SFOC but B20 experiment's show the lowest value at $2200 \mathrm{rpm}$. B20 simulation SFOC value at $1800 \mathrm{rpm}$ is $393.876 \mathrm{gr} / \mathrm{kWh}$ and B20 simulation SFOC value at $2200 \mathrm{rpm}$ is 472.164 $\mathrm{gr} / \mathrm{kWh}$. For B20 experiment, SFOC value at $1800 \mathrm{rpm}$ is $309 \mathrm{gr} / \mathrm{kWh}$ and at $2200 \mathrm{rpm}$ is $304.317 \mathrm{gr} / \mathrm{kWh}$. The difference between lowest for the fuel is about $4 \%$ and between both method is about $29 \%$. 


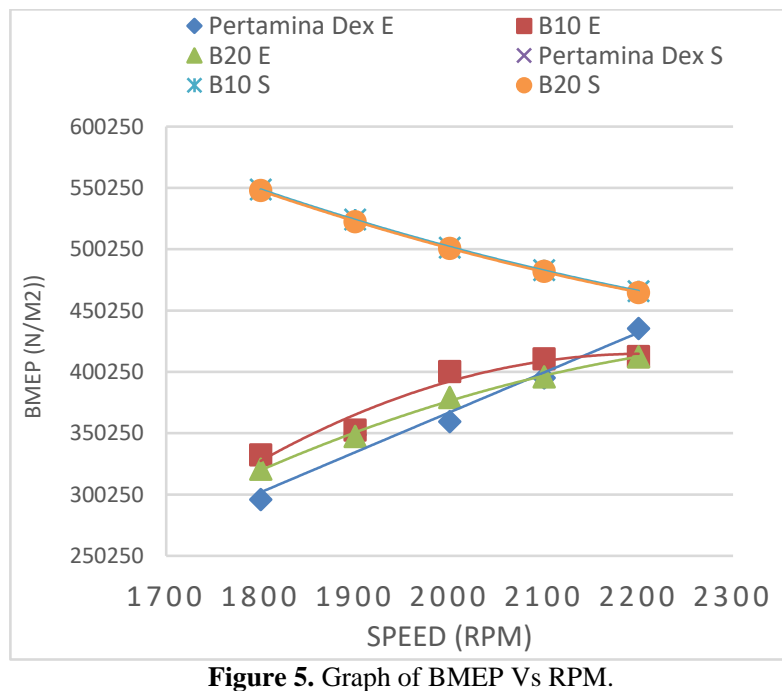

Figure 5 is a graph of the experiment and simulation comparison result between BMEP and rpm in maximum power for each fuel and each method fuel. At the 1800 rpm for Pertamina Dex simulation show the highest value of BMEP but Pertamina Dex experiment's show the lowest value at $2200 \mathrm{rpm}$. Pertamina Dex simulation BMEP value at $1800 \mathrm{rpm}$ is $553595.7 \mathrm{~N} / \mathrm{m}^{2}$ and Pertamina Dex simulation BMEP value at $2200 \mathrm{rpm}$ is $466864.8 \mathrm{~N} / \mathrm{m}^{2}$. For Pertamina Dex experiment, BMEP value at $1800 \mathrm{rpm}$ is $296136.6 \mathrm{~N} / \mathrm{m}^{2}$ and at $2200 \mathrm{rpm}$ is $435684.3 \mathrm{~N} / \mathrm{m}^{2}$. At the $1800 \mathrm{rpm}$ for B10 simulation show the highest value of BMEP but B10 experiment's show the lowest value at $2200 \mathrm{rpm}$. B10 simulation BMEP value at $1800 \mathrm{rpm}$ is $5489385.5 \mathrm{~N} / \mathrm{m}^{2}$ and B10 simulation BMEP value at $2200 \mathrm{rpm}$ is $466161.2 \mathrm{~N} / \mathrm{m}^{2}$. For B10 experiment, BMEP value at $1800 \mathrm{rpm}$ is $332599.1 \mathrm{~N} / \mathrm{m}^{2}$ and at $2200 \mathrm{rpm}$ is $412758.6 \mathrm{~N} / \mathrm{m}^{2}$. At the $1800 \mathrm{rpm}$ for B20 simulation show the highest value of BMEP but B20 experiment's show the lowest value at $2200 \mathrm{rpm}$. B20 simulation BMEP value at $1800 \mathrm{rpm}$ is $548087.9 \mathrm{~N} / \mathrm{m}^{2}$ and B20 simulation BMEP value at 2200 $\mathrm{rpm}$ is $464971.8 \mathrm{~N} / \mathrm{m}^{2}$. For B20 experiment, BMEP value at $1800 \mathrm{rpm}$ is $321068.3 \mathrm{~N} / \mathrm{m}^{2}$ and at $2200 \mathrm{rpm}$ is $412553.9 \mathrm{~N} / \mathrm{m}^{2}$. The difference between lowest for the fuel is about $5 \%$ and between both method is about $33 \%$.

Figure 6 is a graph of the experiment and simulation comparison result of thermal efficiency $\mathrm{Vs} \mathrm{rpm}$ in maximum power for each fuel and each method. At the $1800 \mathrm{rpm}$ for Pertamina Dex simulation show the highest value of Thermal Efficiency but Pertamina Dex experiment's show the lowest value at $2200 \mathrm{rpm}$. Pertamina Dex simulation Thermal Efficiency value at $1800 \mathrm{rpm}$ is $20.52721809 \%$ and Pertamina Dex Thermal Efficiency value at $2200 \mathrm{rpm}$ is $17.24972653 \%$. Pertamina Dex experiment Thermal Efficiency value at $1800 \mathrm{rpm}$ is $23.7397 \%$ and Pertamina Dex Thermal Efficiency value at $2200 \mathrm{rpm}$ is $26.304 \%$. At the 1800 rpm for B10 simulation show the highest value of Thermal Efficiency but B10 experiment's show the lowest value at $2200 \mathrm{rpm}$. B10 simulation Thermal Efficiency value at $1800 \mathrm{rpm}$ is $20.53987 \%$ and B10 Thermal Efficiency value at $2200 \mathrm{rpm}$ is $17.25359 \%$. B10 experiment Thermal Efficiency value at $1800 \mathrm{rpm}$ is $24.7294 \%$ and Pertamina B10 Efficiency value at 2200 rpm is $26.5896 \%$. B20 simulation Thermal Efficiency value at $1800 \mathrm{rpm}$ is $20.55275 \%$ and B20 Thermal Efficiency value at $2200 \mathrm{rpm}$ is $17.26436 \%$. B20 experiment Thermal Efficiency value at $1800 \mathrm{rpm}$ is $25.6065 \%$ and B20 Thermal Efficiency value at 2200 $\mathrm{rpm}$ is $26.7448 \%$.

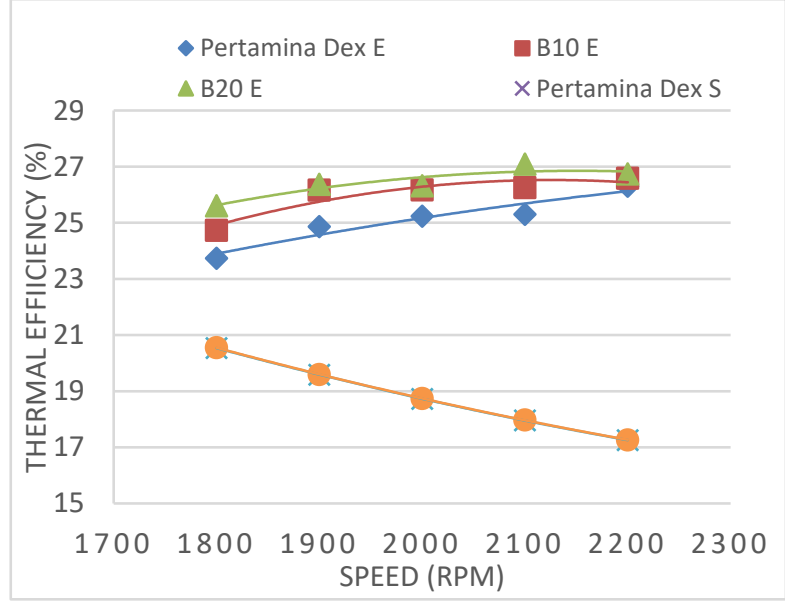

Figure 6. Graph of Thermal Efficiency Vs RPM.

\section{CONCLUSION}

1. Soybean Oil have the potential to be used as biodiesel. In the process of making this biodiesel using transesterification method, the soybean oil can be converted into soybean oil biodiesel. From the properties test result, it can be concluded that soybean oil biodiesel meet the requirement of national biodiesel standard. Soybean Oil Biodiesel properties are : Flash Point value is $182^{\circ} \mathrm{C}$, Pour Point value is $-7^{\circ} \mathrm{C}$, Density at $15^{\circ} \mathrm{C}$ is $890 \mathrm{Kg} / \mathrm{m} 3$, Kinematic Viscosity at $40^{\circ} \mathrm{C}$ is $5.58(\mathrm{cSt})$, and Lower Heating Value is $42.27686 \mathrm{MJ} / \mathrm{kg}$.

2. From the engine performance test, it can be concluded that soybean oil biodiesel mixture of B10 and B20 have lower performance than Pertamina Dex. The highest power, highest torque, and highest BMEP was produced by Pertamina Dex. For the SFOC, B10 have lower value than B20 and the highest value produced by Pertamina Dex. For thermal Efficiency, B20 produced the highest value among B10 and Pertamina Dex. It means soybean oil biodiesel. This result shows that the use of soybean oil biodiesel as the mixture or substitute for Pertamina Dex is better not be done. This is because the result shows the engine performance using B10 and B20 didn't have better result compare to the engine performance using Pertamina Dex.

3. From the engine performance comparison result between experiment and simulation method, it can be concluded that simulation produce higher value in Power, Torque, SFOC, and BMEP than the Experiment.For thermal effciency, Experiment shows higher value than the simulation. For the highest Power that was produced at $2200 \mathrm{rpm}$ for both method. In Experiment, the torque, SFOC, BMEP, and thermal efficiency goes higher as the rpm goes higher. In Simulation, the torque, SFOC, BMEP, and thermal efficiency goes lower as the rpm goes higher.

\section{ACKNOWLEDGMENT}

Gratitude to Mr. Nur Afandi for assisted preparation of research specially for engine set up and experiment. Secondly I would like thanks to all academicians of 
Marine Engineering Department FTK-ITS that helped of the process.

\section{BIBLIOGRAPHY}

[1] Khumbar R and Dange H.M. 2014 .Performance Analysis of Single Cylinder Diesel Engine, Using Diesel Blended with Thumba Oil. International Journal of Soft Computing and Engineering. Blue Eyes Intelligence Engineering,P 24-30.

[2] Sampatrao, D.A., Metkari Ganesh Sunil, M.G., P. D. Kulkarni, P.D. 2014. Performance \& Emission Analysis of Biodiesel Using Various Blends (Castor Oil+ Neem Oil Biodiesel). Impact Journal. Vol.2, P 117-123.
[3] Mielenz, J.R., Bardsley, J.S., Wyman, C.E. 2009. "Fermentation of Soybean Hulls to Ethanol while Preserving Protein Value". Bioresource Technology.

[4] Kargbo, D.M. 2010. "Biodiesel Production from Municipal Sewage Sludges”. Energy Fuels, 24 (5),

[5] Noah,C., and Fathallah A.Z.M. 2011.Unjuk Kerja Diesel Engine Type Direct Injection Dengan Metode Simulasi dan Eksperimen. ITS-Undergraduate Journal. 